\title{
P-25 DEPOSITIONAL CONDITIONS OF MID-EOCENE NUMMULITE ACCUMULATIONS IN THE GULF OF GABES, TUNISIA
}

MANFRED K. HAUPTMAN ${ }^{1}$, JAN BARTHOLDY ${ }^{2}$ and RALF BISCHOFF 'Independent Consultant, Tschajkowskistrasse 16, 13156 Berlin, Germany 'Berlin Free University 3Preussag Energie GmbH

\begin{abstract}
Summary
Nummulitic limestones in the Gulf of Gabes and onshore Central Tunisia i.e. the Early Eocene (Ypresian) El Garia Formation and the Mid-Eocene Reineche Member are generally interpreted as hydrodynamic storm-derived nummulite accumulations. Such models try to explain the characteristic irregular bedding and scattering of nummulites by the occurrence of chaotic turbulent current patterns during storm events.
\end{abstract}

In contrast this presentation is focused on the role of nutrient flux and of bioturbation with respect to primary sedimentary textures and secondary diagenetic features. Various groups of burrowing organisms from the Reineche Member are introduced including echinoids, crabs and bivalves. Subsequently, a model for the depositional environment is proposed based on observations on the nummulite community and associated organisms with special emphasis on the infauna. This model allows explaining the spatial distribution of nummulite accumulations independently from storm events.

\section{Introduction}

The Mid-Eocene (Late Lutetian - Early Bartonian) nummulitic limestones of the Reineche Member have been deposited along a 20-25 km wide NW-trending belt across the Gulf of Gabes offshore Central Tunisia into Libyan waters. Such nummulitic limestones are the reservoir in the Chergui gas condensate field and the adjacent Cercina oil field (Kerkennah West Permit, fig. 1) operated by TPS a joint venture of Preussag Energie (Lingen, Germany) and ETAP (Tunisia).

The facies analysis is based on samples from three Chergui wells. A detailed core description of the Reineche in Chergui 3, Chergui 4, and Chergui 5 supported by large-scale thin-sections up to postcard-size revealed the importance of bioturbation. SEM samples have been taken from all cores including cuttings from Chergui $1 \mathrm{~A}$ for comparison.

\section{Facies}

Two major types of facies are characteristic for the Reineche nummulitic limestones in Chergui, both intermixed by intense bioturbation.

Facies 1 consists of nummulitic packstones with a significant proportion of small nummulite morphotypes. Many nummulites are complete, borings and fracturing are quite rare. The matrix is more argillaceous. Near the base of Chergui 5 oyster-type bivalves are quite common. 


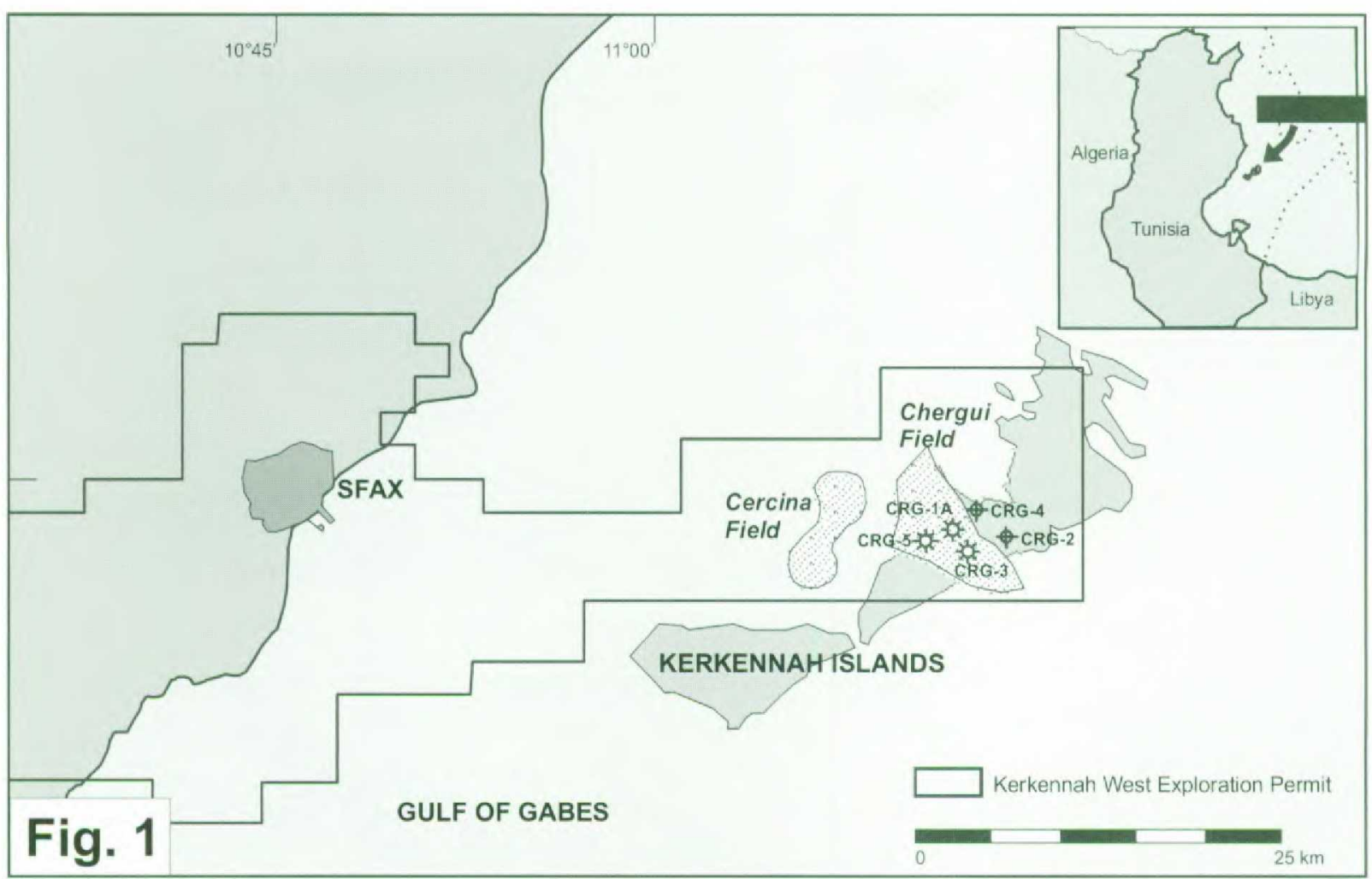

In contrast, facies 2 is characterised by nummulithoclastic nummulite packstones to grainstones dominated by nummulithoclastic debris and a higher proportion of large nummulite morphotypes with common borings. Associated are patches rich in echinodermal debris including echinoid spines, bryozoan fragments, and crab remnants. The matrix is less argillaceous. Remnants of planktonic organisms such as coccoliths and small planktonic foraminifera seem more common in facies 2 also.

Primary sedimentary contacts are generally overprinted by bioturbation resulting in a complex network of both facies types with all kinds of transitional stages. Most obvious are the Thalassinoides-type burrows at the base of the nummulite limestones, where branches cut deeply into underlying calcareous shales.

Diagenesis is obviously related to the tight network of bioturbation, resulting in a patchy irregular distribution pattern of preferential dissolution and cementation including dolomitization and silification. Dolomitization is favoured by the enrichment of echinodermal debris. There is no evidence of meteoric diagenesis.

\section{Depositional Environment}

Reineche nummulites flourished in a transgressive stage around the Lutetian/Bartonian boundary on a flat ramp or shelf below storm wave-base. As strong K-strategists nummulites depended on a long-term stability of the environment. Also the low specific weight of nummulites $<1$ even below the specific weight of echinoderm remnants should have resulted in a long-distance drift of nummulites in range of storm wave-base. While echinoderm fragments are found in all marine environments including beaches and tidal flats, the occurrence of large nummulite morphotypes is restricted to well-defined facies belts. Thus, such facies belts cannot simply resemble death assemblages occasionally created by nummulites in range of storm waves. Large nummulites have probably flourished below storm wave-base along a zone settled by sea grass and/or sea weeds. 


\section{Facies I}

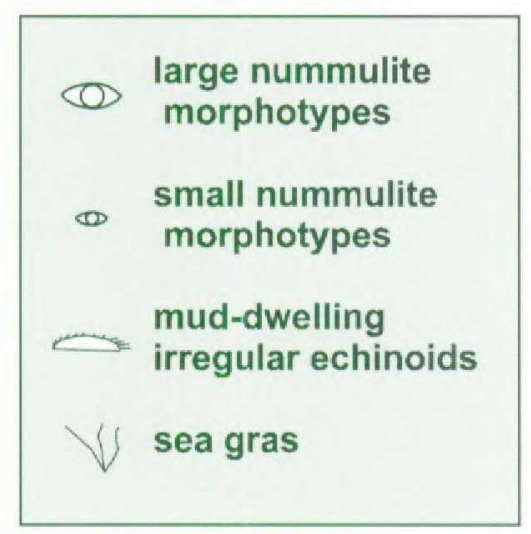

\section{Facies \|}

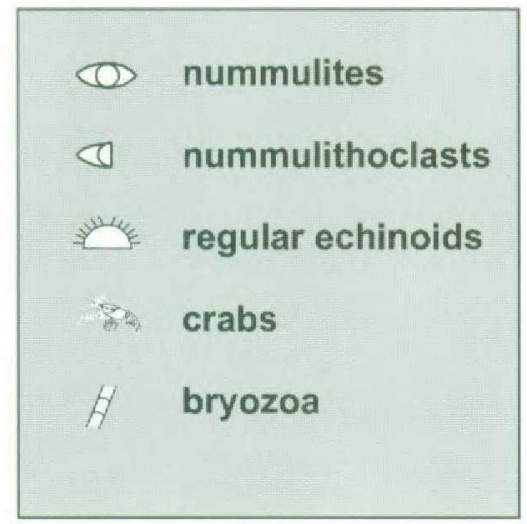

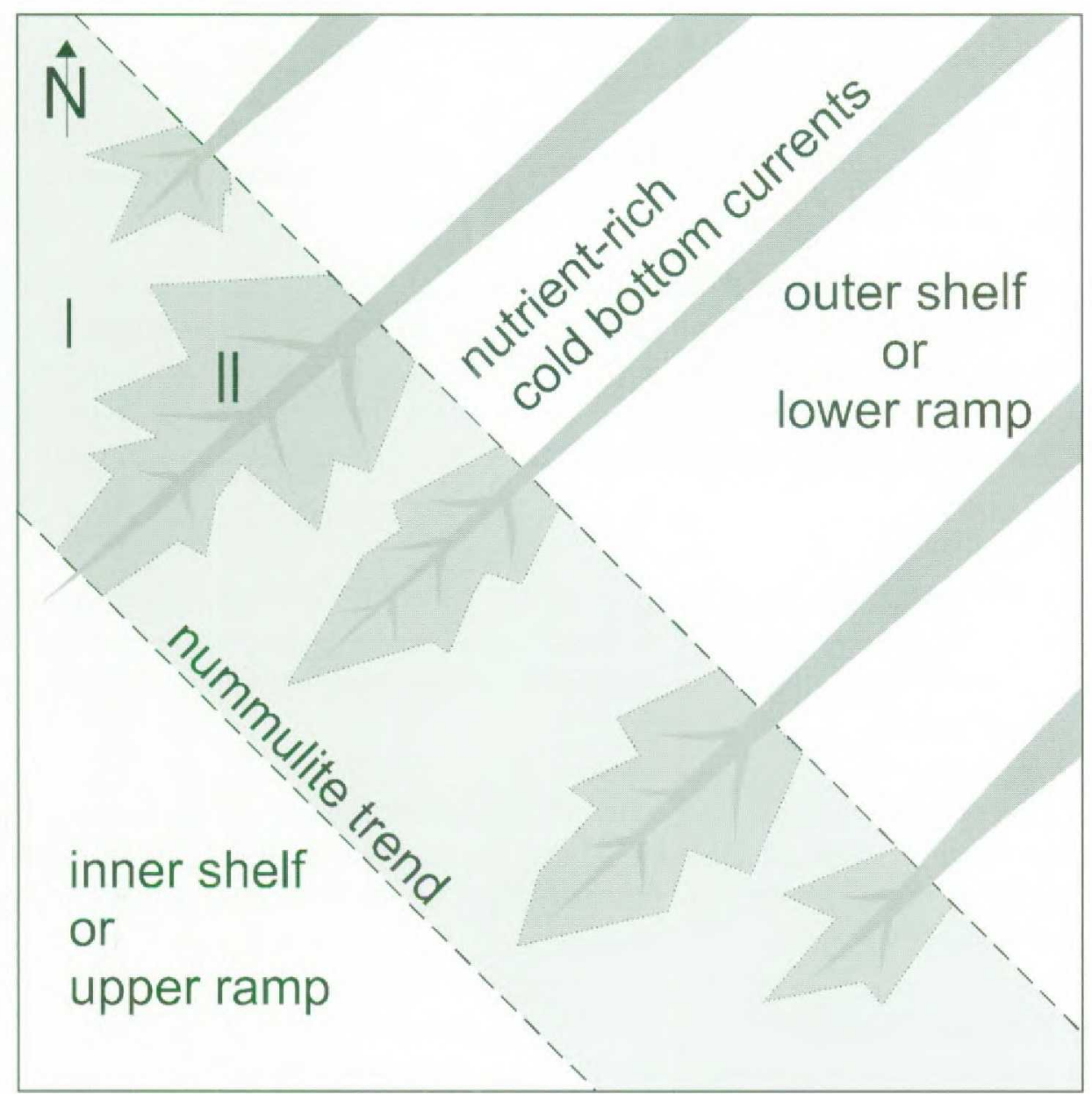

Fig. 2

Consequently, the two major facies reflect subtle variations in nutrient supply and oxygen-content on the sea-bottom only.

Facies 1 corresponds to an oligotrophic situation. Common burrows of irregular mud-dwelling echinoids point to a soft bottom with sufficient oxygen supply on the sea floor. 
In contrast, facies 2 developed along zones respectively through periods of better nutrient supply by nutrient-loaded bottom currents, supporting the partial replacement of nummulites by heterotrophic organisms and resulting in a locally washed-out matrix. A more rapid cementation favoured the replacement of irregular echinoids burrowing in the sea floor by regular forms dwelling on the substrate. Consequently borings on nummulites caused by annelids or bivalves are more common in this facies also. A higher proportion of bioclastic debris could be explained by both the activities of regular echinoids and crabs as well as by bottom currents on the sea floor.

\section{Conclusion \& Perspectives}

The complicated pattern of facies distribution along the Reineche nummulite trend resembles occasional changes in the current pattern on the sea floor such as lateral shifts of local current cells as well as variations in the nutrient load and intensity of currents. The overprint by intense bioturbation resulted in a complex intermix of the two major types of facies. Thus, the accumulation of nummulites in the Reineche Member cannot simply be explained as death assemblage.

Bioturbation allows explaining the irregular textures common in nummulitic limestones. The development of nummulite accumulations is not really favoured by a depositional environment in range of the storm wave-base.

Complicated fractal distribution patterns of dissolution and cementation in nummulitic limestones do not necessarily reflect a complicated diagenetic history. Since bioturbation creates new permeabilities, diagenesis is favoured along zones of bioturbation preferentially.

Connectivities added to the immense primary porosities of nummulitic limestones by bioturbation are a key factor for reservoir properties of nummulitic limestones. A future task for hydrocarbon exploration along nummulite trends will therefore be a better understanding of distribution patterns of bioturbation along nummulite accumulations.

\section{Selected References}

COKEY, E., HALLOCK, P. \& LIDZ, B. H. 1996. Decadal-scale changes in benthic foraminiferal assemblages of Key Largo, Florida. Coral Reefs, 15, 237-248.

HOTTINGER, L. 1997. Shallow benthic foraminiferal assemblages as signal for depth of their deposition and their limitations. Bull Soc. Géol. France, 168(4), 491-505.

KANZEWA, K. 1995. How spatangoids produce their traces: relationship between burrowing mechanism and trace structure. Lethaia, 28, 211-219.

LOUCKS, R. G., MOODY, R. T. J., BELLIS, J. K. \& BROWN, A. A. 1998. Regional depositional setting and pore network systems of the El Garia Formation (Metlaoui Group, Lower Eocene), offshore Tunisia. In: MacGregor, D. S., Moody R. T. J. \& Clark-Lowes, D. D. (eds) Petroleum Geology of North Africa. Geological Society, London, Special Publications 132, 355-374.

RATCLIFFE, K. T., PETTY, D. \& ALDERTON, J. K. 1994. The Reineche Member - Cercina Field, offshore Tunisia: a diagenetically enhanced hydrocarbon reservoir. In: Proceedings of the $4^{\text {th }}$ Tunisian Petroleum Exploration Conference, ETAP Memoire, 7, 459-473.

WELLS, N. A. 1986. Biofabrics as dynamic indicators in nummulite accumulations - discussion. Jour. Sed. Petr., 56(2), 318-320. 